\title{
PENGARUH PENGETAHUAN AKUNTANSI DAN PENGALAMAN USAHA \\ TERHADAP KINERJA UMKM DENGAN PENGGUNAAN INFORMASI AKUNTANSI SEBAGAI VARIABEL INTERVENING (Studi Kasus pada UMKM Kecamatan Tenayan Raya Kota Pekanbaru)
}

\author{
Reni Sovia \\ Fakultas Ekonomi, Universitas Muhammadiyah Riau \\ e-mail: 150301248@gmail.com
}

\begin{abstract}
ABSTRAK
Peningkatan UMKM memiliki beberapa kendala atau masalah. Permasalahan yang dihadapi UMKM yaitu rendahnya kinerja atau produktivitas. Fenomena dari menurunnya kinerja sering dijumpai adalah kemampuan UMKM untuk bertahan, tumbuh dan berkembang. Penelitian ini bertujuan untuk menguji pengaruh pengetahuan akuntansi dan pengalaman usaha terhadap kinerja UMKM dengan penggunaan informasi akuntansi sebagai variabel intervening pada UMKM Kecamatan Tenayan Raya Kota Pekanbaru. Populasi dalam penelitian ini adalah UMKM yang terdapat di Kecamatan Tenayan Raya yang berjumlah 1.809 UMKM. Metode yang digunakan dalam sampel ini adalah purposive sampling. jumlah sampel dalam penelitian ini adalah 32 UMKM. Jenis data yang digunakan adalah data primer dan data skunder. Teknik pengumpulan data dengan survey menggunakan kuesioner. Teknik analisis data dilakukan dengan pendekatan Structural Equation Model (SEM) dengan menggunakan software Partial Least Square (PLS).Pengetahuan akuntansi tidak berpengaruh terhadap kinerja UMKM, pengalaman usaha tidak berpengaruh terhadap kinerja UMKM. Pengetahuan akuntansi berpengaruh signifikan terhadap penggunaan informasi akuntansi, pengalaman usaha berpengaruh signifikan terhadap penggunaan informasi akuntansi, pengetahuan akuntansi berpengaruh terhadap kinerja UMKM.. Pengetahuan akuntansi tidak berpengaruh terhadap kinerja UMKM secara tidak langsung melalui penggunaan informasi akuntansi. Pengalaman usaha berpengaruh terhadap kinerja UMKM secara tidak langsung melalui penggunaan informasi akuntansi.
\end{abstract}

\section{Kata Kunci : Pengetahuan Akuntansi, Pengalaman Usaha, Kinerja UMKM, Penggunaan Informasi Akuntansi}

\section{ABSTRACT}

Increasing MSMEs has several obstacles or problems. The problems faced by MSMEs are low performance or productivity. The phenomenon of declining performance is often encountered is the ability of SMEs to survive, grow and develop. This study aims to examine the effect of accounting knowledge and business experience on MSME performance by using accounting information as an intervening variable in MSMEs in Tenayan Raya District, Pekanbaru City. The population in this study is MSMEs in Tenayan Raya District, amounting to 1,809 MSMEs. The method used in this sample is purposive sampling. the number of samples in this study were 32 SMEs. The type of data used is primary data and secondary data. The technique of collecting data is a survey using a questionnaire. The data analysis technique was carried out using the Structural Equation Model (SEM) approach using Partial Least Square (PLS) software. Accounting knowledge had no effect on MSME performance, business experience had no effect on MSME performance. Accounting knowledge has a significant effect on the use of accounting information, business experience has a significant effect on the use of accounting information, accounting knowledge has an effect on the performance of MSMEs. Accounting knowledge does not affect the performance of MSMEs indirectly through the use of accounting information. 
Business experience affects the performance of MSMEs indirectly through the use of accounting information

\section{Keywords : Budget Clarity, Application Of Regional Financial Accounting, Reporting System, Performance Accountability Of Government Agencies}

\section{PENDAHULUAN}

Usaha Mikro Kecil dan Menengah (UMKM) merupakan salah satu penggerak ekonomi rakyat di Indonesia. Hal ini karena para pengusaha kecil dan menengah berawal dari industri rumahan yang dikelola perorangan maupun badan usaha kecil di sektor ekonomi. UMKM memiliki peran penting dalam pembangunan dan pertumbuhan ekonomi nasional. Sektor UMKM mampu menciptakan lapangan pekerjaan sehingga mengurangi tingkat pengangguran dan menciptakan sumber penghasilan bagi masyarakat. Kontribusi sektor UMKM dalam menentukan Produk Domestik Bruto dan meningkatkan devisa negara juga setiap tahun semakin meningkat. Menurut data Kementerian Koperasi dan Usaha Kecil Menengah tahun 2017 menunjukkan bahwa kontribusi UMKM terhadap Produk Domestik Bruto sebesar 62,57\% atau nilainya sebesar Rp.7.005.950 milyar. Jumlah populasi UMKM Indonesia tahun 2017 mencapai 60 juta unit usaha dengan penyerapan tenaga kerja sebesar 97\% dari total tenaga nasional. Saat ini jumlah usaha kecil di Indonesia sudah mencapai 94,9 persen, dan usaha menengah berada di angka 5,1 persen, sedangkan usaha besar hanya 1 persen. Data ini menunjukkan bahwa UMKM memiliki peran penting dalam perkembangan ekonomi Indonesia.

Pekanbaru sebagai kota yang memiliki iklim bisnis tinggi juga memiliki perkembangan bisnis UMKM yang cukup baik. Jumlah UMKM di Pekanbaru menjadi jumlah terbanyak dibandingkan dengan jumlah UMKM di kabupaten/kota lainnya di Riau. Kota Pekanbaru memiliki jumlah UMKM yang meningkat setiap tahunnya. Berdasarkan data dari Dinas koperasi dan UMKM Kota Pekanbaru data UMKM di Pekanbaru sebagai berikut :

Tabel 1. Jumlah UMKM di Kota Pekanbaru Tahun 2016-2020

\begin{tabular}{cc}
\hline Tahun & Jumlah UMKM \\
\hline 2016 & 13.513 \\
2017 & 13.556 \\
2018 & 13.639 \\
2019 & 13.986 \\
2020 & 15.098 \\
\hline
\end{tabular}

Sumber: Dinas Koperasi dan UMKM Kota Pekanbaru, 2021

Berdasarkan Tabel 1 di atas dapat dilihat bahwa UMKM di Kota Pekanbaru meningkat setiap tahunnya. Namun peningkatan UMKM memiliki beberapa kendala atau masalah. Permasalahan yang dihadapi UMKM yaitu rendahnya kinerja atau produktivitas. Fenomena dari menurunnya kinerja sering dijumpai adalah kemampuan UMKM untuk bertahan, tumbuh dan berkembang, hal ini dapat dilihat dari beberapa UMKM yang tidak bertahan dalam jangka waktu lama atau dengan kata lain usaha yang dijalankan tidak berkelanjutan secara terus menerus. Kinerja UMKM seringkali mengalami kendala, keadaan ini disebabkan oleh masalah internal yang dihadapi UMKM yaitu: rendahnya kualitas SDM UMKM dalam manajemen, organisasi, penguasaan teknologi, dan pemasaran, lemahnya kewirausahaan dari para pelaku UMKM, dan terbatasnya akses UMKM terhadap permodalan, informasi, teknologi dan pasar, serta faktor produksi lainnya. Sedangkan masalah eksternal yang dihadapi oleh UMKM diantaranya adalah besarnya biaya transaksi akibat iklim usaha yang kurang mendukung dan kelangkaan bahan baku juga yang menyangkut perolehan legalitas formal yang hingga saat ini masih merupakan persoalan mendasar bagi UMKM di Indonesia.

Kota pekanbaru menjadi kota yang mendapatkan dampak berlakunya Masyarakat Ekonomi Asean (MEA), saat ini saja secara tidak langsung masyarakat Pekanbaru sadar tidak sadar telah berhadapan langsung dengan pasar bebas tersebut, hal tersebut terlihat mulai dari 
banyaknya produk-produk luar yang membanjiri toko-toko maupun supermarket di Pekanbaru, ditambah lagi persaingan yang terjadi di bidang tenaga kerja professional dimana tidak ada lagi batasan yang di berikan di era MEA saat sekarang ini. Pasar Bebas Asean Sangat kental terasa di masyarakat Pekanbaru, Khusus nya untuk pelaku usaha dibidang UMKM, Persaingan pasar yang dihadapi pelaku usaha UMKM semakin bertambah beratnya dimana produk-produk yang mereka tawarkan akan bersaing dengan produk luar negeri yang mana harga yang di tawarkan produk asing cenderung lebih murah, belum lagi pengawasan yang dilakukan terhadap produk produk tersebut cenderung sangat lemah.(Setiorini et al., 2021)

Persaingan antara produk luar dengan produk UMKM sebagian besar terjadi pada sektor perdagangan. Persaingan produk tersebut menyebabkan kinerja sektor tersebut mengalami penurunan terutama penurunan penjualan, Untuk mengatasi permasalahan yang terjadi, Dinas Koperasi dan UMKM Pekanbaru memberikan kesempatan pada UMKM untuk memiliki kartu izin usaha mikro-kecil (IUMK) yang berguna untuk mendapatkan bantuan modal, pembinaan dan pelatihan. Berdasarkan data yang penulis peroleh, dapat diketahui bahwa Sebagian besar UMKM tersebut bergerak pada sektor perdagangan. IUMK pada sektor perdagangan yang terbanyak adalah di Kecamatan Tenayan Raya. Sehingga dapat diambil kesimpulan bahwa UMKM sektor perdagangan seperti dijelaskan di atas merupakan sektor yang memiliki tngkat persaingan yang tinggi yang dapat menyebabkan UMKM sulit berkembang dan memajukan usahanya. Linawati (2015) mengemukakan bahwa dalam upaya untuk berkembang, UMKM menghadapi berbagai kendala atau masalah antara lain disebabkan rendahnya tingkat pendidikan, pelatihan usaha, pengalaman manajerial, kurangnya pemahaman teknologi informasi dan kurangnya keandalan karakteristik laporan keuangan. Oleh karena itu,perlu dilakukan upaya untuk memetakan pengetahuan pelaku UMKM dalam hal akuntansi, serta upaya perbaikannya sehingga mampu menggunakan informasi akuntansi yang ada, sehingga dapat meningkatkan kualitas pengambilan berbagai keputusan yang dibuatnya.. Hasil penelitian Lestari dan Rustiana (2019) menunjukkan bahwa pengetahuan akuntansi berpengaruh terhadap kinerja UMKM.

Semakin banyak dan baik pengalaman seorang pelaku usaha atas informasi akuntansi, maka akan semakin baik pula kemampuan seorang pelaku usaha dalam mengelola perusahaannya. Seorang pelaku usaha harus berani belajar dari pengalaman orang lain juga, belajar dari kegagalan maupun keberhasilan dimasa-masa yang lalu yaitu proses belajar dalam menunjang keberhasilan dalam meningkatkan kinerja UMKM. Hasil penelitian Tambunan (2019) menunjukkan bahwa pengalaman usaha berpengaruh terhadap kinerja UMKM. Perkembangan UMKM tidak lepas dari masalah pengelolaan keuangannya karena pengelolaan keuangan yang baik membutuhkan ketrampilan akuntansi yang tidak semua pelaku UMKM dapat merealisasikan. Tambunan (2019) menyatakan, Dilihat dari sisi manajemen, kurangnya keahlian terhadap pengaplikasian informasi akuntansi salah satu kelemahan yang mengakibatkan gagalnya UMKM terhadap proses kelangsungan usaha. Kemampuan untuk menyediakan dan menggunakan informasi akuntansi sangat bergantung pada kemampuan pemilik untuk menjalankan teknis akuntansi. Dengan melihat penggunaan informasi akuntansi dalam berbagai aktivitas usaha, informasi akuntansi dipandang potensial karena mampu memberikan kontribusi terhadap berbagai tindakan yang bisa dijadikan pertimbangan dalam perencanaan, pengawasan, pengendalian dan pengambilan keputusan, oleh karena itu para pengusaha kecil dan menengah dituntut untuk memiliki kemampuan menganalisis dan menggunakan data akuntansi. Informasi akuntansi merupakan bagian yang terpenting dari seluruh informasi yang diperlukan manajemen terutama yang berhubungan dengan data keuangan. Sehingga dalam penelitian ini penggunaan informasi akuntansi digunakan sebagai intervening, dengan melihat apakah penggunaan informasi akuntansi bisa mempengaruhi kinerja UMKM. Endiana dan Sudiarta (2016) yang menyatakan bahwa terjadinya permasalahan dalam penerapan akuntansi karena kurangnya pengetahuan pemilik perusahaan tentang akuntansi dan pengalaman usaha. Rendahnya pengetahuan akuntansi pemilik menyebabkan banyak perusahaan kecil yang mengalami kegagalan. Upaya peningkatan kinerja UMKM mutlak 
dilakukan supaya terjaga stabilitas perekonomian nasional, salah satunya melalui penerapan sistem informasi akuntansi.(Paidi Paidi, Yusmaniarti,Y., 2017)

\section{TINJAUAN LITERATUR DAN PERUMUSAN HIPOTESIS}

\section{Human Capital Theory}

Human Capital Theory dikembangkan oleh Becker (1965) yang mengemukakan bahwa investasi dalam pelatihan dan untuk meningkatkan human capital adalah penting sebagai suatu investasi dari bentuk-bentuk modal lainnya. Human Capital Theory berpendapat bahwa investasi sumber daya manusia mempunyai pengaruh yang besar terhadap peningkatan produktivitas, peningkatan produktivitas tenaga kerja ini dapat didorong melalui pendidikan dan pelatihan.

\section{Usaha Mikro Kecil dan Menengah (UMKM)}

Di Indonesia, definisi UMKM diatur dalam Undang-Undang Republik Indonesia No.20 Tahun 2008 tentang UMKM.1 Pasal 1 dari UU terebut, dinyatakan bahwa Usaha mikro adalah usaha produktif milik orang perorangan dan/atau badan usaha perorangan yang memiliki kriteria usaha mikro sebagaimana diatur dalam UU tersebut.

\section{Kinerja UMKM}

Kinerja (performance) dapat diartikan sebagai suatu pencapaian hasil kerja sesuai dengan aturan dan standar yang berlaku pada masig-masing organisasi kerja. Simamora (2014) mengatakan bahwa kinerja merupakan suatu pencapain persyaratanpersyaratan pekerjaan tertentu yang akhirnya secara langsung dapat tercermin dari output yang dihasilkan baik jumlah maupun kualitasnya

\section{Pengetahuan Akuntansi}

Menurut Kamus Besar Bahasa Indonesia pengetahuan berarti segala sesuatu yang diketahui, kepandaian, atau segala sesuatu yang dikatahui berkaitan dengan sesuatu hal. Akuntansi adalah suatu aktivitas jasa, yang menyediakan informasi kuantitatif tentang entitas ekonomi yang bermanfaat dalam pengambilan keputusan ekonomik (Belkaoui, 2000).

\section{Pengalaman Usaha}

Pengalaman merupakan suatu proses pembelajaran dan pertambahan perkembangan potensi bertingkah laku baik dari pendidikan formal maupun nonformal atau bisa diartikan sebagai suatu proses yang membawa seseorang kepada suatu pola tingkah laku yang lebih tinggi.Suatu pembelajaran juga mencakup perubahan yang relatif tepat dari perilaku yang diakibatkan pengalaman, pemahaman dan praktek (Knoers \& Haditono, 2009 dalam Asih, 2012).

\section{Penggunaan Informasi Akuntansi}

Menurut Kamus Besar Bahasa Indonesia penggunaan adalah cara, proses dalam menggunakan sesuatu.Informasi akuntansi adalah suatu informasi kuantitatif yang berkaitan dengan fakta dan data yang dapat dikuantitatifkan satuannya (Halim dan Supomo, 1990). Informasi akuntansi adalah suatu informasi yang penting yang membantu untuk mengatur suatu perusahaan dari berbagai macam masalah yang berkaitan dengan kegiatan ekonomi.

\section{Hipotesis}

\section{Pengaruh Pengetahuan akuntansi terhadap kinerja UMKM}

Pengetahuan akuntansi pemilik dapat tercermin melalui perlakuan pemilik usaha atau manajer dalam mengelola keuangan perusahaan. Dengan kata lain praktik akuntansi dalam suatu perusahaan mencerminkan tingkat pengetahuan akuntansi pemilik. Pengetahuan akuntansi dapat di identifikasi dari pengalaman pemilik usaha atau manajer pada partisipasinya dalam program 
pelatihan akuntansi yang pernah diikuti. Semakin baik pengetahuan akuntansi yang dimiliki oleh pemilik usaha atau manajer, maka semakin baik pula kemampuan mereka sehingga dapat meningkatkan kinerja UMKM. Berdasarkan uraian di atas maka hipotesis yang dirumuskan dalam penelitian ini adalah:

\section{H1 : Pengetahuan Akuntansi berpengaruh terhadap kinerja UMKM}

\section{Pengaruh Pengalaman usaha terhadap kinerja UMKM}

Pengalaman akan membentuk pengetahuan dan ketrampilan serta sikap yang lebih menyatu pada diri seseorang, jika bidang pekerjaan yang ditangani selama masih bekerja merupakan bidang yang sejenis yang pada akhirnya akan membentuk spesialisasi pengalaman diperoleh selama seseorang membuka usaha Banyak sedikitnya pengalaman kerja akan menentukan atau menunjukan bagaimana kualitas dan produktivitas seseorang dalam bekerja, artinya mudah sukarnya atau cepat lambatnya seseorang dalam mengerjakan suatu pekerjaan akan dipengaruhi oleh seberapa banyak orang tersebut telah memiliki pengalaman kerja dalam melaksanakan suatu pekerjaan. Ini berarti pengalaman akan juga mempengaruhi kemampuan dalam bekerja sehingga dapat meningkatkan kinerja usaha;

\section{H2 : Pengalaman usaha berpengaruh terhadap kinerja UMKM}

\section{Pengaruh Pengetahuan akuntansi terhadap penggunaan informasi akuntansi}

Pengetahuan akuntansi dapat didefinisikan sebagai suatu kebenaran atas informasi mengenai pencatatan, pengelompokkan, dan pengikhtisaran kejadian ekonomi untuk pengambilan keputusan. Implikasi Human Capital Theory dalam penelitian ini adalah pengetahuan akuntansi dimiliki oleh pemilik UMKM juga merupakan penentu untuk memberikan persepsi akan penggunaan informasi akuntansi. Motivasi untuk mempelajari tentang pengetahuan akuntansi akan meningkatkan pemahaman manajer atau pemilik untuk menerapkan akuntansi dalam pengelolaan usahanya. Pengetahuan akuntansi juga dapat dimiliki dengan mengikuti pelatihan-pelatihan (pendidikan non-formal). Semakin tinggi motivasi untuk mempelajari akuntansi, maka semakin baik pula pengetahuan akuntansi yang dimiliki, sehingga penggunaan informasi akuntansi oleh pelaku UMKM menjadi hal penting dalam usahanya. Sebaliknya, semakin rendahnya motivasi untuk mempelajari akuntansi, semakin rendah pula pengetahuan akuntansi yang dimiliki, sehingga penggunaan informasi akuntansi menjadi kurang dilakukan oleh pelaku UMKM. Oleh sebab itu, kualitas tingkat pengetahuan akuntansi yang dimiliki pelaku UMKM dapat memberikan pengaruh positif terhadap penggunaan informasi akuntansi.

\section{H3 : Pengetahuan Akuntansi berpengaruh terhadap penggunaan informasi akuntansi}

\section{Pengaruh Pengalaman usaha terhadap penggunaan informasi akuntansi.}

Pengalaman berusaha memperoleh banyak pembelajaran tentang informasi apa yang dibutuhkan dan digunakan dalam pengambilan keputusan. Manajemen perusahaan akan membutuhkan informasi yang lebih banyak akan disiapkan dan digunakan dalam pengambilan keputusan apabila tingkat kompleksitas usaha serta persaingan semakin ketat. Oleh karena itu Nicholls dan Holmes (1989) yang dikutip Fitriyah (2006) mengemukakan bahwa pengalaman dalam operasional berusaha atau lamanya perusahan beroperasi berdasarkan pada bisnis yang sudah dijalankan akan mengindikasikan kebutuhan akan informasi akuntansi sangat diperlukan.

\section{H4 : Pengalaman usaha berpengaruh terhadap penggunaan informasi akuntansi}

\section{Penggunaan Informasi akuntansi berpengaruh terhadap kinerja UMKM.}

Informasi akuntansi mempunyai peran penting untuk mencapai keberhasilan usaha, termasuk bagi usaha kecil (Pinasti, 2007). Informasi akuntansi dapat menjadi dasar yang andal bagi pengambilan keputusan dalam pengelolaan usaha kecil dan menengah, antara lain untuk keputusan penetapan harga, pengembangan pasar, termasuk untuk keputusan investasi (Suhairi, 
dkk., 2004). UMKM membutuhkan informasi akuntansi untuk menilai kesuksesan dan keberhasilan usahanya. Informasi akuntansi dapat berupa pencatatan keuangan dan laporan akuntansi. Dengan meningkatnya penggunaan informasi akan menyebabkan peningkatan kinerja UMKM.

\section{H5 : Informasi akuntansi berpengaruh terhadap penggunaan informasi akuntansi}

\section{Pengetahuan akuntansi berpengaruh terhadap kinerja UMKM melalui penggunaan} informasi akuntansi.

Informasi akuntansi merupakan bagian yang terpenting dari seluruh informasi yang diperlukan manajemen terutama yang berhubungan dengan data keuangan Baridwan (2000) Tujuan informasi akuntansi tersebut adalah memberikan petunjuk dalam memilih tindakan yang paling baik untuk mengalokasikan sumber daya yang langka pada aktivitas bisnis dan ekonomi. Pengetahuan akuntansi yang dimiliki pelaku UMKM dijadikan dasar untuk menggunakan informasi akuntansi untuk pengambilan keputusan terhadap kemajuan usaha yang dijalankannya yang diantaranya adalah meningkatkan kinerja usahanya. Seorang wirausaha yang memiliki kemampuan yang baik tentang pengetahuan akuntansi akan lebih cenderung menggunakan informasi akuntansi.

\section{H6 : Pengetahuan akuntansi berpengaruh kinerja usaha secara tidak langsung melalui penggunaan informasi akuntansi}

\section{Pengalaman usaha berpengaruh terhadap kinerja UMKM melalui penggunaan informasi akuntansi}

Setiap pelaku usaha tentu berbeda antara satu dan lainnya, baik itu mengenai latar belakang pendidikan, latar belakang keluarga dan lain sebagainya. Adapun faktor-faktor yang dapat mempengaruhi persepsi seorang pelaku usaha dari karakteristik pribadinya meliputi sikap, kepribadian, pengalaman. Semakin banyak dan baik pengalaman seorang pelaku usaha atas informasi akuntansi, maka akan semakin baik pula kemampuan seorang pelaku usaha dalam mengelola perusahaannya. Seorang pelaku usaha harus berani belajar dari pengalaman orang lain juga, belajar dari kegagalan maupun keberhasilan dimasa-masa yang lalu yaitu proses belajar dalam menunjang keberhasilan dalam pengembangan usaha. Berdasarkan uraian di atas dapat diketahui pengalaman pelaku UMKM berkaitan dengan penggunaan informasi akuntansi akan dapat meningkatkan kinerja UMKM.

H7 : Pengalaman usaha berpengaruh kinerja usaha secara tidak langsung melalui penggunaan informasi akuntansi

\section{Kerangka Pemikiran}

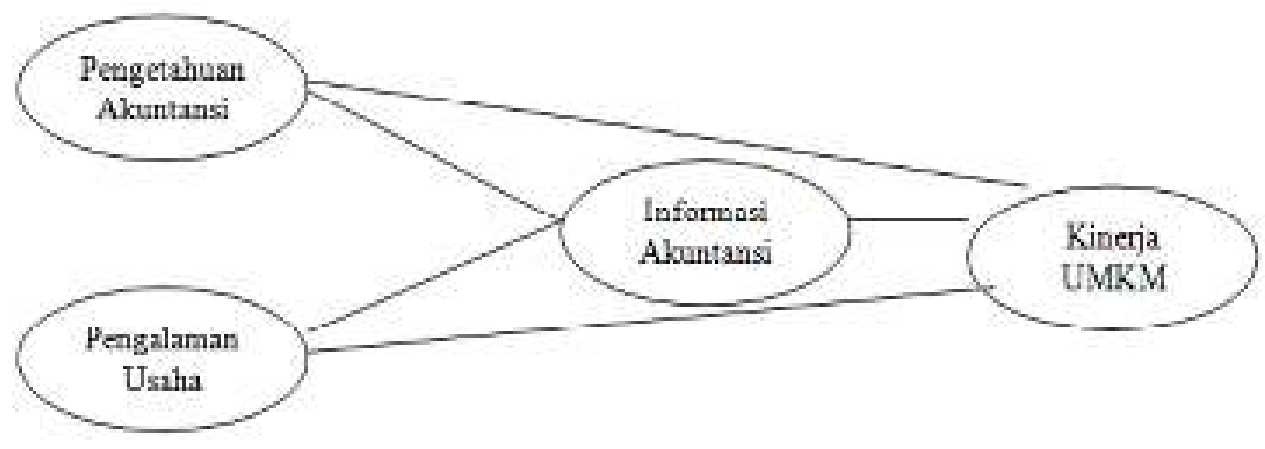

Gambar 1. Kerangka Pemikiran 


\section{METODE PENELITIAN}

Penelitian ini merupakan penelitian kuantitatif. Penelitian ini akan dilakukan pada Usaha Mikro, Kecil dan Menengah (UMKM). Adapun yang menjadi populasi dalam penelitian ini adalah UMKM yang terdapat di Kecamatan Tenayan Raya yang berjumlah 1.809 UMKM. Metode yang digunakan dalam sampel ini adalah purposive sampling. jumlah sampel dalam penelitian ini adalah 32 UMKM. Jenis data yang digunakan adalah data primer dan data skunder. Teknik pengumpulan data dengan survey menggunakan kuesioner. Teknik analisis data dilakukan dengan pendekatan Structural Equation Model (SEM) dengan menggunakan software Partial Least Square (PLS)

\section{HASIL DAN PEMBAHASAN}

\section{Hasil Uji Statistik Deskriptif Variabel Penelitian}

Tabel 2. Hasil Uji Statistik Deskriptif Variabel Penelitian

\begin{tabular}{lccccc}
\hline & & & & & $\begin{array}{c}\text { Std. } \\
\text { Deviation }\end{array}$ \\
\hline Pengetahuan Akuntansi & 32 & 3,00 & 4,75 & 3,93 & 0,47274 \\
Pengalaman Usaha & 32 & 3,33 & 5,00 & 4,01 & 0,45544 \\
Kinerja UMKM & 32 & 3,00 & 5,00 & 3,89 & 0,63905 \\
Penggunaan Informasi & & & & & \\
Akuntansi & 32 & 3,43 & 4,86 & 4,11 & 0,37349 \\
\hline
\end{tabular}

Berdasarkan Tabel 2 diatas dapat dijelaskan statistik deskriptif masing-masing variabel sebagai berikut.

1. Pengetahuan Akuntansi, dapat dilihat bahwa tanggapan responden mengenai pengetahuan akuntansi rata-rata 3,93 yang berarti bahwa pelaku UMKM memberikan tanggapan mengenai pengetahuan akuntansi yang dimiliki tergolong baik.

2. Pengalaman usaha, dapat dilihat bahwa tanggapan responden mengenai pengalaman usaha rata-rata 4,01 yang berarti bahwa pelaku UMKM memberikan tanggapan mengenai pengalaman usaha yang dimiliki tergolong baik.

3. Kinerja UMKM, dapat dilihat bahwa tanggapan responden mengenai kinerja UMKM rata-rata 3,89 yang berarti bahwa pelaku UMKM memberikan tanggapan mengenai kinerja UMKM yang dimiliki tergolong baik.

4. Pengetahuan Informasi Akuntansi, dapat dilihat bahwa tanggapan responden mengenai Pengetahuan Informasi Akuntansi rata-rata 3,97 yang berarti bahwa pelaku UMKM memberikan tanggapan mengenai kinerja UMKM yang dimiliki tergolong baik.

\section{Hasil Evaluasi Model Pengukuran (Outer Model)}

\section{Hasil Uji Validitas Convergent dan Discriminant}

Nilai Average Variance Extracted (AVE) dipaparkan dari hasil estimasi perhitungan Outer Model dengan menggunakan PLS. Berikut data Average Variance Extracted (AVE) terhadap nilai loading factor yang di atas 0,50 .

Tabel 3. Average Variance Extracted (AVE) dan Akar AVE

\begin{tabular}{ccc}
\hline Variabel & AVE & Keterangan \\
\hline $\mathrm{X}_{1}$ & 0,761 & Valid \\
$\mathrm{X}_{2}$ & 0,607 & Valid \\
$\mathrm{Y}$ & 0,686 & Valid
\end{tabular}


$\begin{array}{lll}\mathrm{Z} & 0,581 & \text { Valid }\end{array}$

Tabel 3 menjelaskan nilai AVE dari pengetahuan akuntansi (X1), pengalaman usaha (X2), kinerja akuntansi (Y), dan penggunaan informasi akuntansi (Z), dapat dilihat bahwa setiap konstruk (variabel) tersebut memiliki nilai AVE di atas 0,50. Hal ini menunjukkan bahwa secara keseluruhan kontruk tersebut memiliki nilai validitas yang baik dari setiap indikator kuesioner dan dapat dikatakan bahwa semua konstruk memenuhi kriteria valid. Model indikator dari penelitian ini merupakan model indikator reflektif yang arah hubungan antara variabel dinyatakan dalam koefisien korelasi. Koefisien korelasi positif terbesar $=0.7$ dan korelasi negatif terbesar adalah $-0,7$ sedangkan yang terkecil adalah 0 . Bila besarnya antara dua variabel atau lebih itu mempunyai koefisien korelasi antara $0,70-1$ atau $-0,7-(-1)$, maka hubungan tersebut sempurna. Berikut data Correlation of Laten Variabels disajikan pada Tabel 4 berikut:

Tabel 4. Correlation of Laten Variabels

\begin{tabular}{ccccc}
\hline Variabel & $\mathbf{X}_{\mathbf{1}}$ & $\mathbf{X}_{\mathbf{2}}$ & $\mathrm{Y}$ & $\mathrm{Z}$ \\
\hline $\mathrm{X}_{1}$ & 0,873 & & & \\
$\mathrm{X}_{2}$ & 0,818 & 0,779 & & \\
$\mathrm{Y}$ & 0,835 & 0,842 & 0,828 & \\
$\mathrm{Z}$ & 0,859 & 0,865 & 0,883 & 0,762 \\
\hline
\end{tabular}

Berdasarkan Tabel 4 dapat dijelaskan bahwa hubungan discriminant validity pada penelitian ini mempunyai hubungan yang sempurna karena memiliki koefisien korelasi 0,70.

\section{Hasil Uji Reliabilitas}

Hasil output SmartPLS composite reliability dapat dilihat pada Tabel 5 berikut ini.

Tabel 5. Composite Reliability

\begin{tabular}{ccc}
\hline Variabel & Composite Reliability & Keterangan \\
\hline $\mathrm{X}_{1}$ & 0,927 & Reliabel \\
$\mathrm{X}_{2}$ & 0,822 & Reliabel \\
$\mathrm{Y}$ & 0,929 & Reliabel \\
$\mathrm{z}$ & 0,906 & Reliabel \\
\hline
\end{tabular}

Berdasarkan Tabel 5 dapat disimpulkan bahwa semua kontruk memenuhi kriteria reliabel. Hal ini ditunjukkan dengan nilai composite reliability di atas 0,70 , sebagaimana kriteria yang direkomendasikan.

\section{Hasil Analisis Structural Equation Modeling-Partial Least Square (SEM-PLS) Menilai Outer Model atau Measurement Model}


Hasil output SmartPLS sebagai berikut:

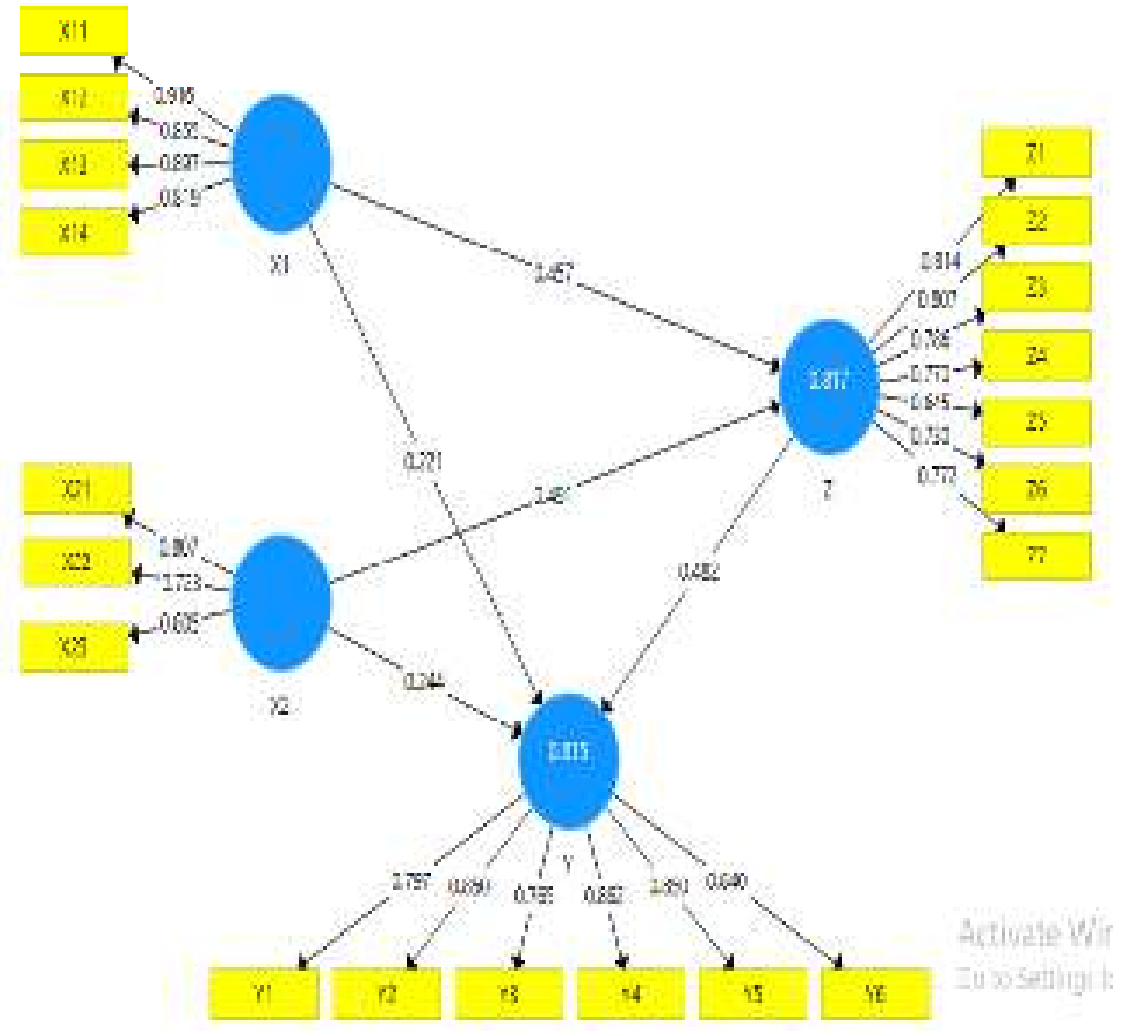

\section{Gambar 2 Full Model Struktural SEM PLS}

Hasil pengolahan dengan menggunakan SmartPLS dapat dilihat Gambar 1 dimana nilai outer loading dari indikator pengetahuan akuntansi (X1), pengalaman usaha (X2), kinerja akuntansi (Y), dan penggunaan informasi akuntansi (Z) tidak terdapat indikator yang berada di bawah 0,50 dan menunjukkan nilai outer model dan korelasi dengan variabel secara keseluruhan sudah memenuhi convergen validity.

\section{Menilai Model Struktural (Inner Model)}

Hasil estimasi $R$ Square dengan menggunakan SmartPLS.

Tabel 6 R Square

\begin{tabular}{lr}
\hline & $\boldsymbol{R}$ Square \\
\hline $\mathbf{Y}$ & 0.815 \\
$\mathbf{Z}$ & 0.817
\end{tabular}

Sumber: Data Olahan (2021)

Tabel 6 menunjukkan nilai $R$ square untuk kinerja UMKM (Y) sebesar 0,815, sedangkan untuk penggunaan informasi akuntansi sebesar 0,817. Hal ini menunjukkan bahwa $81,5 \%$ variabel kinerja UMKM (Y) dipengaruhi oleh pengetahuan akuntansi (X1), pengalaman usaha (X2), dan penggunaan informasi akuntansi (Z). Sedangkan 81,7 \% variabel penggunaan informasi akuntansi (Z), dipengaruhi oleh variabel pengetahuan akuntansi (X1) dan pengalaman usaha $(\mathrm{X} 2)$, 


\section{Pengujian Signifikansi dan Pengujian Hipotesis}

Diperoleh hasil untuk pengaruh langsung dan tidak langsung yang dapat dilihat pada Tabel 7 berikut:

Tabel 7 Path Coefficients dan Specific Indirect Effects

\begin{tabular}{lrrrrr}
\hline & $\begin{array}{c}\text { Original } \\
\text { Sample (O) }\end{array}$ & $\begin{array}{c}\text { Sample } \\
\text { Mean (M) }\end{array}$ & $\begin{array}{c}\text { Standard } \\
\text { Deviation } \\
(\text { STDEV) }\end{array}$ & $\begin{array}{c}\text { T Statistics } \\
(\mid \mathbf{O} / \text { STDEV|) }\end{array}$ & P Value \\
\hline $\mathbf{X 1}$-> Y & 0,221 & 0,199 & 0.174 & 1,273 & 0,204 \\
$\mathbf{X 1}$-> Z & 0,457 & 0.469 & 0.144 & 3,170 & 0,002 \\
$\mathbf{X} 2$-> Y & 0,244 & 0.294 & 0.146 & 1,675 & 0,095 \\
$\mathbf{X} 2$-> Z & 0,491 & 0.485 & 0.146 & 3,355 & 0.001 \\
$\mathbf{Z}$-> Y & 0,482 & 0,458 & 0,187 & 2,570 & 0,010 \\
$\mathbf{X} 1$-> Z -> Y & 0,220 & 0,212 & 0.112 & 1,962 & 0,050 \\
$\mathbf{X} 2$-> Z -> Y & 0,236 & 0.224 & 0.118 & 1,996 & 0,046 \\
\hline
\end{tabular}

Sumber: Data Olahan (2021)

Pada penelitian ini menggunakan $\mathrm{p}$ value. Pengujian ini menggunakan dua arah menggunakan $\mathrm{a}=5 \%(0,05)$, dengan kriteria pengujian apabila $\mathrm{p}$ value $<0,05$ maka ha diterima dan ho ditolak, artinya berpengaruh.

\section{PEMBAHASAN}

\section{Pengaruh Pengetahuan Akuntansi terhadap Kinerja UMKM}

Berdasarkan Tabel 7 di atas dapat dilihat nilai path coefisient sebesar 0,221 dengan nilai $p$ value sebesar 0,2002 . Nilai $p$ value $(0,204)$ lebih besar dari $\boldsymbol{\alpha}(0,05)$. Hasil ini menunjukkan bahwa pengetahuan akuntansi tidak memiliki pengaruh terhadap kinerja UMKM yang berarti tidak sesuai dengan hipotesis pertama dimana pengetahuan akuntansi berpengaruh terhadap kinerja UMKM. Hal ini berarti Hipotesis 1 ditolak. Tidak berpengaruhnya pengetahuan akuntansi terhadap kinerja UMKM diduga disebabkan karena pengetahuan akuntansi belum sepenuhnya berperan penting dalam menjalankan usaha. Sehingga tanpa pengetahuan akuntansi pelaku UMKM dalam menjalankan usahanya dengan baik. Artinya kinerja UMKM meningkat bukan karena pengetahuan akuntansinya baik.

\section{Pengaruh Pengalaman Usaha terhadap Kinerja UMKM}

Berdasarkan Tabel 7di atas dapat dilihat nilai path coefisient sebesar 0,244 dengan nilai $p$ value sebesar 0,095 . Nilai $p$ value $(0,095)$ lebih besar dari $\boldsymbol{\alpha}(0,05)$. Hasil ini menunjukkan bahwa pengalaman usaha tidak berpengaruh pengaruh terhadap kinerja UMKM yang berarti sesuai dengan hipotesis kedua dimana pengalaman usaha berpengaruh terhadap kinerja UMKM. Hal ini berarti Hipotesis 2 ditolak.

Hasil penelitian ini menunjukkan bahwa pengalaman usaha tidak berpengaruh terhadap kinerja UMKM di Kecamatan Tenayan Raya Kota Pekanbaru, hal ini diduga lama atau tidaknya pengalaman usaha belum mampu meningkatkan kinerja UMKM. Hasil penelitian ini membuktikan bahwa jika jika bidang pekerjaan yang ditangani selama masih bekerja merupakan bidang yang sejenis yang pada akhirnya akan membentuk spesialisasi pengalaman diperoleh selama seseorang membuka usaha Banyak sedikitnya pengalaman kerja akan menentukan atau menunjukan bagaimana kualitas dan produktivitas seseorang dalam bekerja, artinya mudah sukarnya atau cepat lambatnya seseorang dalam mengerjakan suatu pekerjaan akan dipengaruhi oleh seberapa banyak orang tersebut telah memiliki pengalaman kerja dalam melaksanakan suatu pekerjaan. Ini berarti pengalaman akan juga mempengaruhi kemampuan dalam bekerja namun belum dapat meningkatkan kinerja usaha.

Menurut Matthewman \& Matignon dalam Gaol (2014:696) human capital sebagai akumulasi pengetahuan, keahlian, pengalaman dan atribut-atribut kekuatan pekerja lainnya yang 
relevan di dalam kekuatan pekerja sebuah organisasi dan memacu produktivitas, kinerja dan pencapaian tujuan strategis. Hasil penelitian ini tidak mendukung hasil penelitian Tambunan (2019) menunjukkan bahwa pengalaman usaha berpengaruh terhadap kinerja UMKM.

\section{Pengaruh Pengetahuan Akuntansi terhadap Penggunaan Informasi Akuntansi}

Berdasarkan Tabel 7 dapat dilihat nilai path coefisient sebesar 0,457 dengan nilai $p$ value sebesar 0,002 . Nilai $p$ value $(0,002)$ lebih kecil dari $\boldsymbol{\alpha}(0,05)$. Hasil ini menunjukkan bahwa pengetahuan akuntansi memiliki pengaruh terhadap penggunaan informasi akuntansi yang berarti sesuai dengan hipotesis kedua dimana pengetahuan akuntansi berpengaruh terhadap penggunaan informasi akuntansi. Hal ini berarti Hipotesis 3 diterima.

Hasil penelitian ini menunjukkan bahwa pengetahuan akuntansi berpengaruh terhadap penggunaan informasi akuntasi pada UMKM di Kecamatan Tenayan Raya Kota Pekanbaru, hal ini disebabkan karena pelaku UMKM sudah memiliki pengetahuan akuntansi yang baik. maka semakin baik pula pengetahuan akuntansi yang dimiliki, sehingga penggunaan informasi akuntansi oleh pelaku UMKM menjadi hal penting dalam usahanya. Sebaliknya, semakin rendah pengetahuan akuntansi yang dimiliki, sehingga penggunaan informasi akuntansi menjadi kurang dilakukan oleh pelaku UMKM. Oleh sebab itu, kualitas tingkat pengetahuan akuntansi yang dimiliki pelaku UMKM dapat memberikan pengaruh positif terhadap penggunaan informasi akuntansi.

Pengetahuan akuntansi yang dimiliki oleh pemilik usaha kecil menengah akan banyak memberikan banyak manfaat dalam penggunaan informasi akuntansi. Pengetahuan akuntansi yang rendah akan menyebabkan usaha yang dijalankan mengalami kegagalan manajemen sehingga sangat sulit bagi para pelaku usaha dalam menentukan kebijakan apa yang akan diambil (Yusuf, 2011 dalam Sitorus 2017). Pengetahuan akuntansi juga merupakan faktor yang mempengaruhi penggunaan informasi akuntansi. Hal ini dapat dilihat dari pendapat Wichman (1984) yang dikutip oleh Setyaningrum (2014) yang menyatakan bahwa terjadinya permasalahan dalam penerapan akuntansi karena kurangnya pengetahuan pemilik perusahaan tentang akuntansi. Rendahnya pengetahuan akuntansi pemilik menyebabkan banyak perusahaan kecil yang mengalami kegagalan. Upaya peningkatan kinerja UMKM mutlak dilakukan supaya terjaga stabilitas perekonomian nasional, salah satunya melalui penerapan sistem informasi akuntansi.

\section{Pengaruh Pengalaman Usaha terhadap Penggunaan Informasi Akuntansi}

Berdasarkan Tabel 7 di atas dapat dilihat nilai path coefisient sebesar -0,491 dengan nilai $p$ value sebesar 0,001 . Nilai $p$ value $(0,001)$ lebih kecil dari $\boldsymbol{\alpha}(0,05)$. Hasil ini menunjukkan bahwa pengalaman usaha memiliki pengaruh terhadap penggunaan informasi akuntansi yang berarti sesuai dengan hipotesis keempat dimana pengalaman usaha berpengaruh terhadap penggunaan informasi akuntansi. Hal ini berarti Hipotesis 4 diterima.

Hasil penelitian ini menunjukkan bahwa pengalaman usaha berpengaruh terhadap kinerja UMKM di Kecamatan Tenayan Raya Kota Pekanbaru. Artinya semakin banyak pengalaman usaha maka penggunaan informasi akuntansi juga meningkat. Pengalaman berusaha memperoleh banyak pembelajaran tentang informasi apa yang dibutuhkan dan digunakan dalam pengambilan keputusan. Manajemen perusahaan akan membutuhkan informasi yang lebih banyak akan disiapkan dan digunakan dalam pengambilan keputusan apabila tingkat kompleksitas usaha serta persaingan semakin ketat. Oleh karena itu Nicholls dan Holmes (1989) yang dikutip Fitriyah (2006) mengemukakan bahwa pengalaman dalam operasional berusaha atau lamanya perusahan beroperasi berdasarkan pada bisnis yang sudah dijalankan akan mengindikasikan kebutuhan akan informasi akuntansi sangat diperlukan.

\section{Pengaruh Penggunaan Informasi Akuntansi terhadap Kinerja UMKM}

Berdasarkan Tabel 7 di atas dapat dilihat nilai path coefisient sebesar 0,482 dengan nilai $p$ value sebesar 0,010 . Nilai $p$ value $(0,010)$ lebih kecil dari $\boldsymbol{\alpha}(0,05)$. Hasil ini menunjukkan 
bahwa penggunaan informasi akuntansi memiliki pengaruh terhadap kinerja UMKM yang berarti sesuai dengan hipotesis kelima dimana penggunaan informasi akuntansi berpengaruh terhadap kinerja UMKM. Hal ini berarti Hipotesis 5 diterima.

Hasil penelitian ini menunjukkan bahwa penggunaan informasi akuntansi dapat mempengaruhi kinerja akuntansi, hal ini menunjukkan bahwa semakin baik penggunaan informasi akuntansi maka kinerja UMKM menjadi meningkat. Menurut Arya dan Maria (2016) informasi akuntansi dapat menjadi dasar untuk pengambilan keputusan bisnis sehingga mempunyai pengaruh yang sangat penting bagi pencapaian keberhasilan usaha, termasuk UKM. Penggunaan informasi akuntansi yang berupa informasi operasi, informasi akuntansi manajemen dan informasi keuangan dapat digunakan para pedagang untuk membantu dalam perencanaan usaha, mengontrol kegiatan usaha, pengambilan keputusan dalam pengelolaan usaha, dengan adanya informasi akuntansi pengguna lebih mudah mengetahui perkembangan usaha yang akan dijalankannya, kemudian selain itu dengan informasi akuntansi dapat mempermudah peminjaman modal usaha, serta untuk melakukan evaluasi sehingga dengan melakukan hal tersebut dapat meningkatkan keberhasilan usaha.(Yusmaniarti, 2014)

\section{Pengetahuan Akuntansi Berpengaruh Terhadap Kinerja UMKM Secara Tidak Langsung Melalui Penggunaan Informasi Akuntansi}

Berdasarkan Tabel 7 di atas dapat dilihat nilai path coefisient sebesar -0,220 dengan nilai $p$ value sebesar 0,050 . Nilai $p$ value $(0,050)$ sama dengan dari $\boldsymbol{\alpha}(0,05)$. Hasil penelitian ini menunjukkan bahwa pengetahuan akuntansi mempunyai pengaruh tidak langsung terhadap kinerja UMKM melalui penggunaan informasi akuntansi. yang berarti sesuai dengan hipotesis keenam dimana pengetahuan akuntansi mempunyai pengaruh tidak langsung terhadap kinerja UMKM Hal ini berarti Hipotesis 6 diterima. Hasil penelitian ini menunjukkan bahwa pengetahuan akuntansi pelaku UMKM sudah baik sehingga dapat meningkatkan penggunaan informasi akuntansi yang dapat menyebabkan meningkatnya kinerja UMK. Hasil penelitian ini mengindikasikan bahwa semakin tinggi penggunaan informasi akuntansi maka akan semakin tinggi juga hubungannya dalam mempengaruhi pengetahuan akuntansi terhadap kinerja UMKM. Menurut Hudha (2017) Informasi akuntansi akan dapat digunakan dengan baik apabila pelaku UMKM memiliki pengetahuan tentang akuntansi. Pelaku usaha akan mengalami kegagalan manajemen karena kesulitan dalam mengambil keputusan apabila pengetahuan akuntansi yang dimiliki rendah. Semakin baik pengetahuan akuntansi yang dimiliki oleh pemilik usaha atau manajer, maka semakin baik pula kemampuan mereka dalam menggunakan informasi akuntansi (Setyaningrum, dkk, 2014).

\section{Pengalaman Usaha Berpengaruh Terhadap Kinerja UMKM Secara Tidak Langsung Melalui Penggunaan Informasi Akuntansi}

Berdasarkan Tabel 7 di atas dapat dilihat nilai path coefisient sebesar 0,236 dengan nilai $p$ value sebesar 0,000 . Nilai $p$ value $(0,046)$ lebih kecil dari $\boldsymbol{\alpha}(0,05)$. Hasil penelitian ini menunjukkan bahwa pengalaman usaha mempunyai pengaruh tidak langsung terhadap kinerja UMKM melalui penggunaan informasi akuntansi. yang berarti sesuai dengan hipotesis ketujuh dimana pengalaman usaha mempunyai pengaruh tidak langsung terhadap kinerja UMKM Hal ini berarti Hipotesis 7 diterima. Hasil penelitian ini menunjukkan bahwa pengalaman pelaku UMKM sudah baik sehingga dapat meningkatkan penggunaan informasi akuntansi yang dapat menyebabkan meningkatnya kinerja UMKM. Hasil penelitian ini mengindikasikan bahwa semakin baik pengalaman usaha maka penggunaan informasi akuntansi akan semakin sehingga dapat mempengaruhi kinerja UMKM. Menurut Sukriani, Dewi, \& Wahyuni (2018) seseorang yang memiliki pengalaman luas akan lebih mudah berinteraksi dalam melaksanakan suatu pekerjaan. Pengalaman usaha yang dimiliki atau lamanya perusahaan dalam beroperasi mampu mengindikasikan kebutuhan penggunaan informasi akuntansi (Ariono \& Sugiyanto, 2018).

Holmes dan Nicholls (1989) yang dikutip Setyaningrum, dkk (2013) mengemukakan bahwa penggunaan informasi akuntansi dipengaruhi oleh usia usaha (lamanya suatu usaha 
berdiri mulai dari awal beroperasi hingga saat ini). Studi tersebut menyatakan bahwa semakin muda usia perusahaan terdapat kecenderungan untuk menyatakan informasi akuntansi yang ekstensif untuk tujuan membuat keputusan apabila dibandingan dengan perusahaan yang lebih tua usianya, sehingga perusahaan yang semakin muda usianya cenderung menggunakan informasi akuntansi dengan lebih optimal guna mencapai tujuannya tersebut.

\section{KESIMPULAN}

Pengetahuan akuntansi tidak berpengaruh terhadap kinerja UMKM, pengalaman usaha tidak berpengaruh terhadap kinerja UMKM. Pengetahuan akuntansi berpengaruh signifikan terhadap penggunaan informasi akuntansi, pengalaman usaha berpengaruh signifikan terhadap penggunaan informasi akuntansi, pengetahuan akuntansi berpengaruh terhadap kinerja UMKM.. Pengetahuan akuntansi tidak berpengaruh terhadap kinerja UMKM secara tidak langsung melalui penggunaan informasi akuntansi. Pengalaman usaha berpengaruh terhadap kinerja UMKM secara tidak langsung melalui penggunaan informasi akuntansi

\section{DAFTAR PUSTAKA}

Ahyaruddin, M dan Akbar R (2017). Akuntabilitas dan kinerja instansi pemerintah: Semu atau nyata? Jurnal Akuntansi \& Auditing Indonesia, Vol. 21No.2,Desember 2017

Bastian, I (2014). Sistem Akuntansi Sektor Publik, Edisi 2. Jakarta:Salemba Empat.

Cantika, Y (2018). Pengaruh Perencanaan Anggaran, Kejelasan Sasaran Anggaran, Sistem Pelaporan Dan Sistem Pengendalian Internal Terhadap Akuntabilitas Kinerja Pemerintahan Kabupaten Polewali Mandar.

Hidayatullah,A \& Herdjiono (2014) Pengaruh Kejelasan Sasaran Anggaran, Pengendalian Akuntansi, Sistem Pelaporan terhadap Akuntabilitas Kinerja SKPD di Merauke. Unisbank ISBN 978-979-3649-81-8

Khairunsyah dan Yulia E (2018). Pengaruh Kejelasan Sasaran Anggaran, Sistem Pelaporan, Kompetensi Terhadap Akuntabilitas Kinerja Instansi Pemerintah Dimediasi Oleh Komitmen Organisasi (Studi Pada Organisasi Perangkat Daerah Kabupaten Kampar) Jurnal Tepak Manajemen Bisnis, Vol. X. No. 1. Januari 2018.

Mardiasmo. (2012) Akuntansi Keuangan Dasar. Yogyakarta: BPFE.

Donaldson, L. \& Davis, J., (1991). Stewardship Theory or Agency Theory: CEO Governance and Shareholder Returns. Academy of Management Review, 20(1), p. 65.

Mulyadi AR, Syamsidar, \& Efendy. (2019). Pengaruh Sistem Pelaporan dan Kejelasan Sasaran Anggaran Terhadap Akuntanbilitas Kinerja Instansi Pemerintah (Studi Pada Satuan Kerja Pemerintah Aceh). Jurnal Riset Inspirasi Manajemen dan Kewirausahaan. Vol 2. No 2.

Nordiawan, D \& Hertianti, A. ( 2010), Akuntansi Sektor Publik. Edisi Kedua. Jakarta:Salemba Empat

Putra, Andi Perna.. (2017) Determinan Akuntabilitas Kinerja Pemerintah Di Kabupaten Lombok Barat. Jurnal Ekonomi dan Keuangan.

Paidi Paidi, Yusmaniarti,Y., D. W. (2017). Membuat Laporan Keuangan Menggunakan MYOB Versi 19.6 (S. Empat (ed.); Edisi 1). Salemba Empat Jakarta.

Setiorini, H., Yuniarti, R., \& Bengkulu, U. M. (2021). Peran Inovasi dalam Total Quality Management dan Kinerja Organisasi. 14(2), 150-157.

Yusmaniarti, Yusmaniarti, B. A. (2014). Pengaruh Penyajian Informasi Akuntansi pemerintahan daerah terhadap transparansi dan akuntabilitas publik ( studi pada pemerintahan kota Bengkulu). PPE Press Fakultas Ekonomi Dan Bisnis Universitas Muhammdiyah Surakarta, 563-576. 
Suyanto, M. Ali Z, (2015). Kejelasan Sasaran Anggaran, Pengendalian Akuntansi, Sistem Pelaporan dan Akuntabilitas Kinerja Instansi Pemerintah pada Inspektorat Jenderal Kementerian Agama RI. Jurnal Riset Akuntansi dan Perpajakan JRAP Vol. 2, No. 1, Juni 2015, hal 89 - 96

Zulfiandri, A (2017)..Faktor-Faktor yang memengaruhi Akuntabilitas Kinerja Instansi Pemerintah (Studi empiris pada OPD di Pemerintah Provinsi Banten). Jurnal Riset Akuntansi. JRA Tirtayasa. Vol 2 No 1 (2017) 